HIV AND ASSISTED REPRODUCTIVE TECHNOLOGIES

\title{
Use of assisted reproductive technology to reduce the risk of transmission of HIV in discordant couples wishing to have their own children where the male partner is seropositive with an undetectable viral load
}

\author{
H W G Baker, A Mijch, S Garland, S Crowe, M Dunne, D Edgar, G Clarke, P Foster, J Blood
}

The advances in treatment of HIV and the introduction of polymerase chain reaction assay for the virus now make it acceptable for HIV discordant couples where the male partner is seropositive to attempt to conceive through artificial insemination by husband (AIH) or via in vitro fertilisation. With undetectable viral load and washed sperm, there is minimal risk of transmission of HIV to the female partner, children, other patients, or staff. We describe the development of a programme of AIH for HIV discordant couples and the reasoning behind offering such a programme.

See end of article for authors' affiliations

Correspondence to: Dr H W G Baker, 132 Grattan Street, Carlton, Melbourne, 3053 Australia; g.baker@ unimelb.edu.au

Revised version received 10 June 2002

Accepted for publication 30 May 2003
$\mathrm{T}$ reatment of patients with HIV infection has improved substantially following the introduction of highly active antiretroviral therapy (HAART). Many patients are now well, are no longer at risk of opportunistic disease or imminent death, and appear to have a good prognosis for many years of life. A number of couples are now attempting to have their own children. On the basis that isolating the motile sperm from the semen should reduce the risk of transmitting the virus, several groups have performed artificial insemination by husband (AIH). There are reports of hundreds to thousands of AIH treatments in HIV discordant couples without infection of the woman. However, infection can occur in women conceiving by natural sexual intercourse with HIV positive men. It is now possible to quantify the amount of virus (HIV RNA) in body fluids by polymerase chain reaction (PCR) assays which are currently used for monitoring treatment. A group in Spain reported the use of PCR for assessing washed sperm preparations from HIV infected men. ${ }^{1}$ Using samples with negative PCR tests for AIH resulted in no transmission of HIV. While plasma HIV RNA below the limit of detection $(<50$ copies HIV RNA $/ \mathrm{ml})$ is associated with lower risks of disease and lower levels of HIV in semen with lower chances of transmission, reservoirs of HIV may remain in cells in semen and there must be a finite albeit very low risk of transmission from a male with apparently completely suppressed plasma HIV.
PROPOSAL FOR OFFERING AIH TO HIV DISCORDANT COUPLES

To date couples with the man HIV infected and the woman negative have been treated by our group with donor insemination. Because of improved treatment of HIV, many patients intend to have their own children and we now consider it appropriate to assist couples minimise the risk of HIV transmission when using their own gametes.

After detailed discussions with the staff and assessment of conscientious objection to being involved in the procedures, the semen and embryology laboratories have been audited and passed by the infection control team for compliance with standard precautions procedures. A quantitative PCR method has been modified and validated for detection of HIV-l in seminal plasma.

Our proposal is to offer AIH, in vitro fertilisation (IVF), or intracytoplasmic sperm injection (ICSI) to couples using sperm stored while there was no detectable HIV in the man's serum, seminal plasma, or prepared sperm suspensions. Several semen samples will be collected over several weeks ( $\sim 3-6$ weeks) and stored frozen. During this time the man will keep a health diary to document intercurrent illness or other changes which may be associated with HIV replication. All the blood plasma and semen samples will be tested for HIV by PCR and if all samples are below the detection limit, it is reasonable to assume that the stored semen samples are suitable for use. Also, as sperm preparation involves removal of the seminal plasma and cells other than sperm, this further reduces the risk of infection.

A team approach will be used. An infectious diseases specialist will evaluate and manage the HIV infected patients. Microbiologists will coordinate and supervise the preparation of samples for HIV testing and the other infectious disease screening tests and supervise the assays of HIV viral load. Infertility specialist clinicians and counsellors will perform fertility assessments,

Abbreviations: $\mathrm{AlH}$, artificial insemination by husband; ART, assisted reproductive technology; HAART, highly active antiretroviral therapy; ICSI, intracytoplasmic sperm injection; IVF, in vitro fertilisation; PCR, polymerase chain reaction 
counselling about the procedures and risks, and the treatments. Lastly, an obstetrician who is an expert in the management of patients with chronic viral illnesses will care for the pregnant women.

\section{TREATMENT OF HIV INFECTION}

Treatment of patients with HIV infection has improved substantially since 1996 with the introduction of combination treatment, so called HAART. HIV infection has a variable course with some patients being seropositive for up to 20 years with no symptoms of the disease and low levels of virus in the blood. The introduction of HAART and PCR assays to monitor the amount of virus in blood (viral load) has had a major impact in patients with progressive disease converting it to a controllable chronic illness in most. ${ }^{2}$ However resistance to these drugs commonly develops with eventual progression or relapse. Alternatively drug toxicities limit the durability of benefit. Current antiretroviral therapy will reduce viral load in $70 \%$ of patients but in about $20 \%$ of these, levels rise again with time. In $30 \%$, the viral load does not fall. At present, approximately half the patients on HAART have undetectable viral loads. It is probable that the levels of HIV can be reduced by modification of therapy in a number of the patients with detectable viral loads. This would allow a period when semen could be collected and stored frozen while there is undetectable HIV viral load in the blood and semen.

\section{RISKS OF SEXUAL TRANSMISSION OF HIV}

Much is now known about the factors affecting transmission of HIV. ${ }^{3}$ Although sexual activity is the major mode of transmission of the epidemic worldwide, generally the risk of transmission from a infected man to a woman by heterosexual intercourse is low, about 1 in 1000 (95\% confidence limits 1 in 2000 to 1 in 400 ). The average estimated risks of infection from a infected person per event are for: needle stick 1 in 333, untreated mother to baby 1 in 5, mother to baby with perinatal zidovudine treatment 1 in 12.5 , and blood transfusion 95 in 100. ${ }^{3}$ Many other factors are involved in the susceptibility to infection with HIV ranging from mutations of a chemokine receptor gene reducing susceptibility to infection to coincidental genital tract abrasions or inflammatory lesions which increase the chance of transmission during sexual intercourse. Barrier contraception is effective in controlling the spread of the disease and is strongly promoted and widely accepted by discordant couples. In addition, the stage of the disease is important, patients being more infectious during the primary infection and later stages of AIDS. The blood levels of virus may vary with activation of the immune system by immunisation or intercurrent illness. ${ }^{3}$ Antiretroviral therapy also reduces infectiousness through reducing viral load. The virus and infected T4 cells appear to enter semen via the lower genital tract as vasectomy does not alter the viral load in semen. ${ }^{4}$ Levels of virus vary in the semen generally in parallel with those in blood, but at a lower level. ${ }^{5-8}$ Several studies have shown that the risk of heterosexual HIV transmission in persons with a low viral load and no active sexually transmissible disease is very low. ${ }^{9-16}$

HIV virus enters T4 lymphocytes and macrophages by binding to $\mathrm{CD} 4$ and chemokine receptors on the plasma membrane. Spermatozoa do not have CD4 receptors and are unlikely to be a major source of infection but there are reports of virions being seen by electron microscopy on and in spermatozoa and HIV DNA being detected in sperm and spermatogenic cells. ${ }^{17-22}$

The electron microscopic studies showing HIV in sperm are disputed..$^{123-27}$ Human oocytes and follicular cells do not have receptors for HIV. Incubation of human oocytes with cell free HIV does not result in infection as can be determined by electron microscopy or PCR. ${ }^{28}$ Thus male to female infection during coitus is likely to be via free virus in semen entering dendritic cells in the vaginal epithelium or direct blood contact through breaches in the epithelial surfaces. ${ }^{32}$ Viral levels in semen are likely to be the critical factor. ${ }^{9}$ While plasma HIV RNA below the limit of detection $(<50$ copies HIV RNA/ml) is usually associated undetectable levels of HIV in semen and low chances of transmission, reservoirs of HIV may persist in cells in semen. ${ }^{30}$ Thus there must remain a finite albeit low risk of transmission from a male with apparently completely suppressed plasma HIV.

\section{FERTILITY IN HIV INFECTED INDIVIDUALS}

A number of couples are conceiving naturally by having unprotected intercourse or home insemination at the time of ovulation however a number of cases of transmission of HIV have occurred. For example, Mandelbrot et al described 104 pregnancies conceived naturally in 92 women. ${ }^{31}$ There were no seroconversions in the first three months of pregnancy but two seroconversions at seven months of pregnancy and two post partum.

Ryder et al followed 178 married discordant couples in Kinshasa over 310 person years with an intensive monthly counselling protocol. ${ }^{16}$ Of the 92 male infected/female negative couples the HIV seroconversion frequency in the women was 3.7 per 100 years of follow up and the pregnancy rate was 8.6 per 100 years of follow up. Most of the couples only had unprotected sex during the fertile phase of the cycle to attempt to achieve a pregnancy. In all, six women became infected: only one woman who conceived (4\%, 95\% confidence interval $0 \%$ to $22 \%$ ).

The Australian Research Centre in Sex, Health and Society performed a survey in August to October 1999 of HIV infected men and women. ${ }^{32}$ Although this report is about infected women there is also information about men's attitudes to having children in the future (table 1). It can be seen that less than $4 \%$ of infected men are trying or may try to have children. Thus the requirement for assistance with conception will be infrequent from this group of people.

The national donor insemination service in France (CECOS) reported their experience with donor insemination for discordant couples in which the male was HIV infected. From 258 inquiries from couples since the mid 1980s, 56 had conceived one or more children by donor insemination. Follow up of these revealed that 48 men were stable, one man had AIDS, four had died, and three were lost to follow up. While these were encouraging results, a number of couples did not continue after the first interview. Others were advised not to continue fertility treatment or were refused treatment for lifestyle reasons (11th World Congress on In Vitro Fertilisation and Human Reproductive Genetics 9 to 14th May 1999, Sydney).

The US Centres for Disease Control investigated a case of transmission of HIV by AIH performed some years

Table 1 HIV infected men's intentions about having children

\begin{tabular}{lc}
\hline Question & Men n (\%) \\
\hline No I am not considering having a child & $783(92)$ \\
I have decided to have a child/children in the future & $12(1.4)$ \\
I am currently trying to conceive/get pregnant & 0 \\
I have thought about it but I haven't decided & $20(2.4)$ \\
I have thought about it but I have decided that it is too risky & $31(3.7)$ \\
l/we are currently pregnant & 0 \\
Total & 846
\end{tabular}

From a complex uncertainty table 24, ARCSHS 1999 survey of 62 heterosexual, 56 bisexual, and 728 gay men. ${ }^{32}$ 
ago in the USA. Infection was considered to have resulted from carry over of the virus from semen as the procedure involved insemination of a crude centrifuged pellet from the semen. ${ }^{33}$

Semprini in Milan has the greatest experience with AIH with sperm from HIV infected men. He used a method of sperm preparation believed to reduce the level of virus and was the first to report pregnancies by AIH. There were no seroconversions in the 29 women or their babies. ${ }^{34}$ Then in 1997 he reported 200 pregnancies with no HIV seroconversions from more than 1000 AIH treatments of over 350 women. ${ }^{35}$ However, because of the low rate of sexual transmission of HIV per episode the safety of Semprini's approach is not proven. HIV has been spread by donor insemination before screening of donors and quarantining semen was routine. ${ }^{36} 37$ There is also concern about the effectiveness of sperm washing in removing infectious virus present in semen. ${ }^{38}$ Thus there was not a high acceptance of this approach by reproductive medicine clinicians. However the use of assays to demonstrate undetectable viral load in semen has resulted in many groups reconsidering treatment of HIV discordant couples. ${ }^{139-41}$ Marina et al reported the use of PCR to check for undetectable HIV in sperm preparations before assisted reproductive technology (ART): either AIH or ICSI, with no seroconversions in women or babies. ${ }^{140}$ The results were reviewed by Gilling-Smith. ${ }^{42} 43$

The Francophone Society held a mini-symposium at the 11th World Congress on In Vitro Fertilisation and Human Reproductive Genetics (9 to 14th May 1999, Sydney) "Childbearing and management of pregnancies in couples sero-discordant for HIV". Dr Semprini presented his experience with AIH with washed sperm from HIV infected men (1725 inseminations, 243 (14\%) pregnancies, 37 miscarriages, 5 ectopic pregnancies, 18 ongoing pregnancies, and 184 delivered pregnancies). Initially he relied on sperm washing but recently has incorporated tests for viral load. He updated the reports on IVF treatment for HIV discordant couples from Marina et al in Spain. So far 80 treatment cycles have been performed with PCR negative samples with a $27 \%$ pregnancy rate (13 pregnancies, 6 ongoing, 7 delivered). Overall, Semprini estimated that by 1999 there had been no transmissions of HIV out of 2300 AIH or IVF cycles using washed sperm from HIV infected men. Generally, it was felt that assisting couples to conceive using their own sperm in the case of a HIV infected man and negative woman was reasonable. As HIV virus may be found in the cell free fraction or the cellular fraction of the semen, washing sperm for AIH or using IVF or ICSI should markedly reduce any potential for transmission, should the virus be present but undetectable. Measuring viral load in blood and seminal plasma should detect possible compartmentalisation of HIV in the semen when no virus is detectable in blood plasma.

In France couples with low ( $<20000$ copies/ml) as well as undetectable viral loads are now treated, as the risk of transmission is considered to be acceptably low however the treatments of HIV infected couples are performed "separated by time or space" from uninfected patients. That is a series of HIV discordant couples are treated at a time when no other patients are treated - that is, separation in time-or separate designated facilities are used for the HIV infected and uninfected patients, separation in space. ${ }^{44}$

Gilling-Smith et al indicate that HIV infected patients are being treated in the UK. ${ }^{43}$ They point out that it is unreasonable to deny treatment to infected couples when there is free access to ART for patients with other illnesses such as diabetes and congenital heart disease, which might affect both their longevity and their children's health.

There is little experience of treating HIV infected patients in Australian ART centres. A number of couples are now attempting to have their own children. ${ }^{32}$ To date those who have approached Reproductive Services of the Royal Women's Hospital for assistance where the man is HIV infected and the woman HIV negative have been treated with donor insemination.

\section{IMPACT OF ASSOCIATED OR INCIDENTAL INFECTIONS}

Other infections might be transmitted during treatment that could infect the female partner or the baby such as hepatitis $\mathrm{B}, \mathrm{C}$, and G, and cytomegalovirus (CMV). ${ }^{45}$ Some of the HIV infected men are also positive for these. Cross contamination of hepatitis B virus between samples of bone marrow during a cryopreservation procedure has been described. ${ }^{46}{ }^{47}$ Nosocomial spread of hepatitis C between patients in an IVF programme has also occurred but probably not through the oocyte collection or embryo transfer procedures. ${ }^{48}$ Hepatitis C does not appear to be in semen. ${ }^{49}$ Our service follows infection control guidelines (standard precautions) and regularly treats hepatitis B and C infected patients some of whom have been on antiviral therapy. We believe the clinical and laboratory procedures are adequate to minimise the risk of transfer of infectious agents.

\section{IMPACT OF HIV AND TREATMENT ON FERTILITY}

Any acute or chronic disease and especially febrile illnesses can impair spermatogenesis. ${ }^{50}$ Patients with AIDS have abnormal semen. ${ }^{51-53}$ However HIV infected men who are well appear to have no specific changes in semen analysis. ${ }^{54}$ Specific HAART causes a number of side effects and some drugs could have an effect on spermatogenesis but this does not appear to be severe. The antiretroviral and other treatments may also have mutagenic effects. ${ }^{55} 56$

\section{TREATMENT PROTOCOL Clinical procedures}

We have developed a treatment protocol to assist discordant couples with the male seropositive but with undetectable HIV by PCR in blood and seminal plasma in order to minimise the risk of transmission to the female partner and child if a pregnancy occurs and also to staff and other patients. A guideline for the counselling and preparation of the couples is shown in box 1 . The patients will receive expert care from a team including: reproductive services staff who will perform fertility assessments and the ART treatments, a specialist infertility counsellor who will see all couples about the procedures and risks, an infectious diseases expert will evaluate and manage the HIV infected patients, microbiologists will assist with the preparation of samples for testing and perform the other infection screening tests and supervise the assays of HIV viral load, and an obstetrician used to managing patients with chronic viral illnesses will manage the pregnant patients.

The choice of which treatment (intrauterine AIH, IVF, or ICSI) is used will be left up to the patients. The added reduction in risk with further dilution and washing of the sperm by using IVF must be balanced against the greater medical intervention and cost. While ICSI would be expected to reduce the risk further because only a single sperm is injected into the cytoplasm of the oocyte with a few femtolitres of fluid, the oocyte is probably not susceptible to infection with external virus as they lack receptors. Thus, the risk may be actually increased because injecting virus into the oocyte may cause an infection. In the future other approaches could be considered, such as treating the sperm samples to destroy the virus without damaging the sperm or growing the embryos to later cleavage or blastocyst stages and checking for infection on embryo biopsies before transferring the embryos to the uterus. 
Box 1 A clinical and counselling guideline for couples discordant for a chronic viral illness

Clinical evaluation (reproductive services staff) Male partner

History

- Exposure category, onset, and nature of illness

- Treatment history, efficacy, and side effects

- Other past illnesses, infertility factors

Examination

- Physical features of the illness

- General examination

- Other factors

Investigations (as for semen donors)

- Screening: HIV, hepatitis B, C, and G viruses, cytomegalovirus, syphilis, Neisseria gonorrhoeae culture of semen

- Genetic factors: haemophilia, cystic fibrosis, thalassaemia, other

Prognosis

Female partner

History

- General health

- Gynaecological history

- Menstrual cycles

Examination

- General

- Gynaecological

Investigations

- Screening as for male partner (above) plus rubella

- Progesterone assay confirmation of ovulation

- Pelvic ultrasound and other tests as necessary

Infectious diseases consultation (infectious diseases specialist)

- Planning antiviral therapy during semen storage

Counselling reproductive (services counsellors)

- Strength of marital relationship

- Management with respect to illness

- Implications for family formation

- Problem of a loss of partner at a young age

General discussion with couple (clinicians and counsellors)

- Pros and cons and relative risks of: natural conception, AlH, IVF, ICSI, donor insemination, or accepting no children

- Risk of infection of mother and child

- Inability to guarantee no risk

- Ethical and legal aspects

Consenting couples with undetectable viral load in blood and two semen samples collected more than seven days apart and between seven and 60 days from the start of semen cryopreservation. Several semen samples will be collected over 3-6 weeks and stored frozen. Because immune activation can result in changes in viral load levels, patients will be monitored carefully during semen storage and the man will keep a health diary. Finally, another blood sample will be checked for virus within two weeks of the last semen sample. All blood and semen samples will be assayed for viral load by PCR for HIV RNA. An assay has been validated for use with seminal plasma. ${ }^{57}$ Also prepared sperm suspension from each semen sample will be assayed for HIV proviral DNA. There are reports that peripheral plasma samples could be undetectable but that seminal plasma may be positive and compartmentalisation has also been described with different genotypes of virus in blood or other tissues and in semen. ${ }^{30} 58-60$ Thus assays of semen are necessary.

The possibility of covering female partners with HAART or other antiviral therapy such as is used for post exposure prophylaxis has been considered but discarded because of the potential teratogenic effects of the antiviral agents. The women will be screened for sexually transmitted infections as an active lesion in the genital area increases the risk of being infected. The women will be monitored for appearance of the virus in the blood two weeks after inseminations and for seroconversion at intervals. The woman will be tested for HIV antibodies in blood before treatment, monthly during treatment, and in the first, third, and eighth months of pregnancy. Samples of plasma will be stored for HIV PCR. The families will be followed up at one year intervals for five years and then five year intervals thereafter. Ongoing counselling will be available from reproductive services counsellors and medical staff

\section{Medical risks of the treatment protocol}

Risks to other patients and staff

Risks to other patients and staff are minimal because of the universal employment of standard precautions. To reduce the likelihood of exposure, patients will have undetectable viral loads in the blood and semen before samples are stored and a portion of each sample will be tested before use. Experienced virology staff will prepare the samples for assay of viral load. Only semen and sperm samples known to have undetectable viral load will be handled in the standard andrology and IVF laboratories.

Risks to the woman

The risk of infecting the woman with HIV or other infectious agents should be minimal. The transfer to the uterus of sperm or embryos developing from sperm prepared from semen samples with undetectable viral load should remove most of the risk, but zero risk cannot be guaranteed. Cohabiting HIV discordant couples have a continuing risk of seroconversion of the negative partner. The proposed procedures should substantially reduce the risk over that in couples who attempt to get pregnant by natural intercourse or home insemination.

Risks to the child

Minimising risks of infecting the woman should also make infection of the child very unlikely. There may be some risk of transmission by other means from the partner to the child but this has not occurred from reported donor insemination treatments of such discordant couples. The possibility of the father dying prematurely is a factor but has not prevented us from treating other couples suffering from potentially fatal illnesses or using donor insemination in HIV discordant couples.

\section{LEGAL AND ETHICAL ISSUES}

This protocol is designed for harm minimisation. It will reduce the risk of transmitting while assisting the small 
Box 2 Elements of the chronic viral illness consent form

Use of assisted reproductive technology (ART) to reduce the risk of transmission of HIV in discordant couples.

- We acknowledge that the male partner has HIV that may be transmitted to his partner or child in various ways including medical techniques used to assist conception.

- We understand that testing for HIV virus in blood and semen and washing the sperm may reduce the risk of transmission of HIV. We acknowledge that some risk of transmission of the HIV virus still remains.

- Using these techniques should reduce the risk of HIV infection of the woman to less than 1 in 2000 per treatment. If the female partner became infected there would be about a 1 in 3 chance of a baby being infected during the pregnancy, childbirth, or lactation. With antiviral therapy, caesarean section, and avoidance of breast feeding the risk of the child of an infected mother becoming infected is reduced to less than 1 in 50.

- We understand that other viruses may be transmitted, including CMV and hepatitis viruses. We understand that blood tests to screen for CMV and hepatitis B and $C$ will be taken and the implications of the results will be discussed with us.

- We understand that there may be additional risks associated with the medication for the chronic viral illness.

- We agree to hold the Women's and Children's Health, it's advisers and their agents without fault or liability if transmission of the illness occurs whether or not the transmission resulted from the procedures used to assist conception.

number of serodiscordant couples requesting treatment to have their own children. Without this service a number of the couples may attempt to conceive by themselves despite the strong advice of the infectious diseases clinicians that the risks are unacceptable. ${ }^{61631}$ Discrimination against the couples on the grounds of previous lifestyle is probably illegal and on the grounds of chronic illness or genetic disease, unfair. ${ }^{61}$

\section{Legal aspects}

In Victoria, ART is regulated by the Infertility Treatment Act 1995 and the Infertility Treatment Authority (ITA). The use of artificial insemination with living husband's semen is unrestricted by the Infertility Treatment Act 1995. While the Infertility Treatment Act 1995 restricts IVF treatment to infertile people or those likely to transmit a serious genetic disease, discussions with the ITA indicate that s.8 Infertility Treatment Act 1995 can be interpreted that IVF and ICSI could be used legitimately to reduce the risks of transmission of infectious diseases and that the recent more stringent interpretation of the law (relating to the use of ART for treatment of single and lesbian women) which requires that the women must be "medically infertile" in the opinion of their doctor, does not apply to these HIV discordant couples. Most patients will try AIH initially and few will choose IVF or ICSI to further minimise the risk of transmission. Thus we may only use IVF or ICSI if AIH failed or if either the female or male partner is infertile.

A law also applies to the use of donor semen requiring a statement about exposure to chronic viral illnesses, a quarantine period, and negative screening tests for HIV and hepatitis $\mathrm{C}$ tests. This does not apply to semen from a woman's partner.

\section{Staff education and conscientious objection}

Two groups at the Royal Women's Hospital have been involved in the development of this proposal since 1998: the HIV Issues Coordination Group and a working group on ART for discordant couples. There have been many meetings and the topic has been presented at several reproductive service clinical meetings. No one has expressed an objection to being involved in the treatment of these patients.

The semen and embryology laboratories are audited for the standard precautions procedures regularly by the hospital's infection control team and also have current National Association of Testing Authorities (NATA) and Reproductive Technology Accreditation Committee (RTAC) accreditation.

\section{Ethics committee, regulatory bodies, and legal opinions}

Referral of a proposed consent from to the hospital's lawyers raised concern about liability. The project was then discussed at the hospital executive committee and a further delay was recommended so that there could be wider consultation and referral to a clinical ethics committee to be set up. The project was therefore discussed at a postgraduate clinical education session in the section "Access to Reproductive Medicine" in September 2000. The general attitude appeared to be that while risk could not be completely removed the patients' informed consent should suffice. No one expressed the opinion that this project should not proceed. The project was also discussed with the Licensing Committee of the ITA in December 2000. They were in favour and indicated that IVF and ICSI could be used to minimise the risk of transmission of a disease. It was then considered by a newly established clinical ethics committee, Clinical Ethics Advisory Group in February 2002, who unanimously felt that the proposal was ethically sound but suggested some modification of the consent form. Finally the hospital's lawyers reconsidered the consent form (box 2) and indemnity issues and recommended the hospital's insurers should be shown the matter for express approval. The insurers were happy to cover the hospital and its staff, and executives of the hospital authorised commencement of the service after notifying the Board. The use of the HIV PCR assay is specifically regulated by the Therapeutic Goods Administration (TGA). Initial advice was that the assay could not be used to monitor viral load in seminal plasma without formal approval requiring a supplier sponsored application which was impossible as the cost would have been outside any possible hope of recovery because of the limited application of the test. After further negotiation the TGA agreed the assay could be used for an unapproved purpose as a further risk reduction strategy. The legal advisors of the Burnet Centre recommended that it not be involved in the use of the assay to avoid any possibility of litigation. Therefore it was necessary to employ a scientist at the Royal Women's Hospital and perform the assays in the molecular microbiology laboratory.

\section{Authors' affiliations}

H W G Baker, University of Melbourne, Department of Obstetrics and Gynaecology and Melbourne IVF Reproductive Services, Royal Women's Hospital, Melbourne, Australia

A Mijch, Victorian HIV/AIDS Services, Department of Infectious Diseases, Alfred Hospital, Melbourne, Australia

S Garland, Clinical Microbiology and Infectious Disease, Infection Control, Royal Women's Hospital, Melbourne, Australia

S Crowe, AIDS Pathogenesis Research Unit, Macfarlane Burnet Institute for Medical Research and Public Health, Melbourne, Australia

M Dunne, Clinical Research Laboratory, Macfarlane Burnet Institute for Medical Research and Public Health, Melbourne, Australia 
D Edgar, Melbourne IVF Reproductive Services, Royal Women's Hospital, Melbourne, Australia

G Clarke, Andrology Laboratory, Royal Women's Hospital, Melbourne, Australia

P Foster, Melbourne IVF Reproductive Services, Royal Women's Hospital, Melbourne, Australia

J Blood, Melbourne IVF Reproductive Services, Royal Women's Hospital, Melbourne, Australia

\section{REFERENCES}

1 Marina S, Marina F, Alcolea R, et al. Human immunodeficiency virus type 1serodiscordant couples can bear healthy children after undergoing intrauterine insemination. Fertil Steril 1998;70:35-9.

2 Chiasson MA, Berenson L, Li W, et al. Declining HIV/AIDS mortality in New York City. J Acquir Immune Defic Syndr Hum Retrovirol 1999;21:59-64.

3 Royce RA, Sena A, Cates W, et al. Sexual transmission of HIV. N Engl J Med 1997;336:1072-8. (Correction N Engl J Med 1997;337:799.)

4 Krieger JN, Nirapathpongporn A, Chaiyaporn M, et al. Vasectomy and human immunodeficiency virus type 1 in semen. $J$ Urol 1998;159:820-5 discussion 825-6.

5 Fiscus SA, Vernazza PL, Gilliam B, et al. Factors associated with changes in HIV shedding in semen. AIDS Res Hum Retroviruses 1998;14(suppl 1): S27-31.

6 Leynaert B, Downs AM, de Vincenzi I. Heterosexual transmission of human immunodeficiency virus: variability of infectivity throughout the course of infection. European Study Group on Heterosexual Transmission of HIV. Am J Epidemiol 1998;148:88-96.

7 Milman G, Sharma O. Mechanisms of HIV/SIV mucosal transmission. AIDS Res Hum Retroviruses 1994;10:1305-12.

8 Vernazza PL, Gilliam BL, Dyer J, et al. Quantification of HIV in semen: correlation with antiviral treatment and immune status. AIDS 1997; 11:987-93.

9 Chakraborty H, Sen PK, Helms RW, et al. Viral burden in genital secretions determines male-to-female sexual transmission of HIV-1: a probabilistic empiric model. AIDS 2001;15:621-7.

10 Lee TH, Sakahara N, Fiebig E, et al. Correlation of HIV-1 RNA levels in plasma and heterosexual transmission of HIV-1 from infected transfusion recipients. J Acquir Immune Defic Syndr Hum Retrovirol 1996;12:427-8.

11 Lusher JM, Operskalski EA, Aledort LM, et al. Risk of human immunodeficiency virus type 1 infection among sexual and nonsexual household contacts of persons with congenital clotting disorders. Pediatrics 1991;88:242-9.

12 Operskalski EA, Stram DO, Busch MP, et al. Role of viral load in heterosexual transmission of human immunodeficiency virus type 1 by blood transfusion recipients. Transfusion Safety Study Group. Am J Epidemiol 1997; 146:655-61.

13 Pedraza MA, del Romero J, Roldan F, et al. Heterosexual transmission of HIV1 is associated with high plasma viral load levels and a positive viral isolation in the infected partner. J Acquir Immune Defic Syndr Hum Retrovirol 1999;21:120-5.

14 Quinn TC, Wawer MJ, Sewankambo N, et al. Viral load and heterosexual transmission of human immunodeficiency virus type 1. Rakai Project Study Group. N Engl J Med 2000;342:921-9.

15 Ragni MV, Faruki H, Kingsley LA. Heterosexual HIV-1 transmission and viral load in hemophilic patients. J Acquir Immune Defic Syndr Hum Retrovirol 1998; 17:42-5.

16 Ryder RW, Kamenga $C$, Jingu $M$, et al. Pregnancy and HIV-1 incidence in 178 married couples with discordant HIV-1 serostatus: additional experience at an HIV-1 counselling centre in the Democratic Republic of the Congo. Trop Med Int Health 2000;5:482-7.

17 Baccetti B, Benedetto A, Burrini AG, et al. HIV-particles in spermatozoa of patients with AIDS and their transfer into the oocyte. J Cell Biol 1994; 127:903-14

18 Baccetti B, Benedetto A, Burrini AG, et al. HIV particles detected in spermatozoa of patients with AIDS. J Submicrosc Cytol Pathol 1991;23:339-45

19 Baccetti B, Benedetto A, Collodel G, et al. The debate on the presence of HIV-1 in human gametes. J Reprod Immunol 1998;41:41-67.

20 Bagasra O, Farzadegan H, Seshamma T, et al. Detection of HIV-1 proviral DNA in sperm from HIV-1-infected men. AIDS 1994:8:1669-74.

21 Bagasra O. Freund M. Weidmann J, et al. Interaction of human immunodeficiency virus with human sperm in vitro. J Acquir Immune Defic Syndr 1988;1:431-5

22 Dussaix E, Guetard D, Dauguet C, et al. Spermatozoa as potential carriers of HIV. Res Virol 1993; 144:487-95.

23 Mermin JH, Holodniy M, Katzenstein DA, et al. Detection of human immunodeficiency virus DNA and RNA in semen by the polymerase chain reaction. J Infect Dis 1991;164:769-72.

24 Piomboni P, Baccetti B. Spermatozoon as a vehicle for HIV-1 and other viruses: a review. Mol Reprod Dev 2000:56:238-42.

25 Quayle AJ, Xu C, Mayer KH, et al. T lymphocytes and macrophages, but not motile spermatozoa, are a significant source of human immunodeficiency virus in semen. J Infect Dis 1997;176:960-8.

26 Quayle AJ, Xu C, Tucker L, et al. The case against an association between HIV-1 and sperm: molecular evidence. J Reprod Immunol 1998:41:127-36.

27 Wolff $\mathrm{H}$, Mayer K, Seage G, et al. A comparison of HIV-1 antibody classes, titers, and specificities in paired semen and blood samples from HIV-1 seropositive men. J Acquir Immune Defic Syndr 1992;5:65-9.
28 Baccetti B Benedetto A, Collodel G et al. Failure of HIV-1 to infect human oocytes directly. J Acquir Immune Defic Syndr 1999;21:355-61

29 Soto-Ramirez LE, Renjifo B, McLane MF, et al. HIV-1 Langerhans' cell tropism associated with heterosexual transmission of HIV. Science 1996;271:1291-3.

30 Nunnari G Otero M Dornadula G et al Residual HIV-1 disease in semina cells of HIV-1-infected men on suppressive HAART: latency without on-going cellular infections. AIDS 2002; 16:39-45.

31 Mandelbrot L, Heard I, Henrion-Geant E, et al. Natural conception in HIVnegative women with HIV-infected partners. Lancet 1997;349:850-1.

32 McDonald K, Grierson J, de Visser R, et al. A complex uncertainty: women and health, hope and living with HIV in Australia. Melbourne: The Australian Research Centre in Sex, Health and Society, La Trobe University, 2000:55.

33 CDC, Control CFD. HIV-1 infection and artificial insemination with processed semen. Morb Mortal Wkly Rep 1990;39:249-56.

34 Semprini AE, Levi-Setti P, Bozzo M, et al. Insemination of HIV-negative women with processed semen of HIV-positive partners. Lancet 1992;340:1317-19.

35 Semprini AE, Fiore S, Pardi G. Reproductive counselling for HIV-discordant couples. Lancet 1997:349:1401-2.

36 Araneta MR, Mascola L, Eller A, et al. HIV transmission through donor artificial insemination. JAMA 1995;273:854-8

37 Wortley PM, Hammett TA, Fleming PL. Donor insemination and human immunodeficiency virus transmission. Obstet Gynecol 1998:91:515-8.

38 Tachet A, Dulioust $E$, Salmon D, et al. Detection and quantification of HIV-1 in semen: identification of a subpopulation of men at high potential risk of viral sexual transmission. AIDS 1999;13:823-31.

39 Lasheeb AS, King J, Ball JK, et al. Semen characteristics in HIV-1 positive men and the effect of semen washing. Genitourin Med 1997;73:303-5.

40 Marina S, Marina F, Alcolea R, et al. Pregnancy following intracytoplasmic sperm injection from an HIV-1-seropositive man. Hum Reprod 1998; 13:3247-9.

41 Rasheed S, Li Z, Xu D. Human immunodeficiency virus load. Quantitative assessment in semen from seropositive individuals and in spiked seminal plasma. J Reprod Med 1995:40:747-57.

42 Gilling-Smith C. HIV prevention. Assisted reproduction in HIV-discordant couples. AIDS Read 2000;10:581-7.

43 Gilling-Smith C, Smith JR, Semprini AE. HIV and infertility: time to treat. There's no justification for denying treatment to parents who are HIV positive. BMJ 2001;322:566-7.

44 Jouannet $P$, de Almeida M, Dulioust $E$, et al. Assisted reproduction for HIVand/or HCV-infected patients. IFFS 2001 The 17th World Congress on Fertility and Sterility. In: Healy GTKDL, McLachlan R, Rodriguez-Armas O, eds. London: The Parthenon Publishing Group, 2001:152-62.

45 Rasmussen L, Morris S, Hamed K, et al. Human cytomegalovirus DNA is present in CD45+ cells in semen from human immunodeficiency virus-infected patients. J Infect Dis 1995; 171:432-6.

46 Fountain D, Ralston M, Higgins $N$, et al. Liquid nitrogen freezers: a potentia source of microbial contamination of hematopoietic stem cell components. Transfusion 1997;37:585-91.

47 Tedder RS, Zuckerman MA, Goldstone AH, et al. Hepatitis B transmission from contaminated cryopreservation tank. Lancet 1995;346:137-40.

48 Lesourd F, Izopet J, Mervan C, et al. Transmissions of hepatitis C virus during the ancillary procedures for assisted conception. Hum Reprod 2000; 15:1083-5

49 Semprini $A E$, Persico $T$, Thiers $V$, et al. Absence of hepatitis $C$ virus and detection of hepatitis $G$ virus/GB virus $C$ RNA sequences in the semen of infected men. J Infect Dis 1998;177:848-54.

50 Baker HWG. Reproductive effects of nontesticular illness. Endocrinol Metab Clin N Am 1998;27:831-50.

51 Crittenden JA, Handelsman DJ, Stewart GJ. Semen analysis in human immunodeficiency virus infection. Fertil Steril 1992:57:1294-9.

52 Laudat A, Blum L, Guechot J, et al. Changes in systemic gonadal and adrenal steroids in asymptomatic human immunodeficiency virus-infected menrelationship with the CD4 cell counts. Eur J Endocrinol 1995;133:418-24

53 Poretsky L, Can S, Zumoff B. Testicular dysfunction in human immunodeficiency virus-infected men. Metab Clin Exp 1995:44:946-53.

54 Muller CH, Coombs RW, Krieger JN. Effects of clinical stage and immunological status on semen analysis results in human immunodeficiency virus type 1-seropositive men. Andrologia 1998;30:15-22.

55 Lorenzi $\mathbf{P}$, Spicher VM, Laubereau B, et al. Antiretroviral therapies in pregnancy: maternal, fetal and neonatal effects. Swiss HIV Cohort Study, the Swiss Collaborative HIV and Pregnancy Study, and the Swiss Neonatal HIV Study. AIDS 1998; 12:F241-7.

56 Olaitan A, Reid W, Mocroft A, et al. Infertility among human immunodeficiency virus-positive women: incidence and treatment dilemmas. Hum Reprod 1996;11:2793-6.

57 Dunne AL, Allen K, Mitchell FM, et al. Analysis of HIV-1 viral load in seminal plasma samples. J Clin Virol 2002;26:239-45.

58 Coombs RW, Speck CE, Hughes JP, et al. Association between culturable human immunodeficiency virus type 1 (HIV-1) in semen and HIV-1 RNA levels in semen and blood: evidence for compartmentalization of HIV-1 between semen and blood. J Infect Dis 1998;177:320-30.

59 Kiessling AA, Fitzgerald LM, Zhang D, et al. Human immunodeficiency virus in semen arises from a genetically distinct virus reservoir. AIDS Res Hum Retroviruses 1998; 14(suppl 1):S33-41.

60 Zhu T, Wang N, Carr A, et al. Genetic characterization of human immunodeficiency virus type 1 in blood and genital secretions: evidence for viral compartmentalization and selection during sexual transmission. J Virol 1996:70:3098-107.

61 Drapkin Lyerly A, Anderson J. Human immunodeficiency virus and assisted reproduction: reconsidering evidence, reframing ethics. Fertil Steril 2001;75:843-58. 